\title{
Chironji (Buchanania lanzan): A Retreating Valuable Resource of Central India
}

\author{
Sunil Prasad \\ Ecology and Biodiversity Services (EBS), Ring Road Dehradun, Uttarakhand, India
}

Corresponding author: ebsddn@gmail.com

Received: $21-12-2019$

Revised: $17-04-2020$

Accepted: 23-05-2020

\begin{abstract}
Minor forest products have been a source of livelihood of millions of forest dwellers in India and other developing and third world countries. The seeds of Buchanania lanzan (Chironji) - a tree species belonging to the family Anacardiacae are commercially very useful for rural tribal people in various parts of India. The seeds/kernels of the plant yield fatty oil which is a substitute for olive and almond oils and widely used in confectionery as well as in the Indigenenous Medicine System (IMS). Due to unsustainable extraction of the seeds natural regeneration of Chironji has become a major issue among environmentalists and field biologists during the last few decades. The species listed in the Red Data Book of IUCN as a vulnerable medicinal plant species. The present article deals with the assessment of the nutritive/economic value of Chironji and regeneration techniques which might be helpful in the conservation and enhancement of this valuable species. The study reveals that the species have great nutritive values having indigenous and industrial significance. Vegetative propagation has shown good results compared to direct seed sowing. The conservation of the species can be promoted by adopting better regeneration techniques and creating awareness among primary collectors and suggesting appropriate scientific harvesting practices.
\end{abstract}

Keywords: Chironji, Regeneration, Conservation, Nutritional Content, Kernel

Buhanania lanzan, was first reported by Francis Hamilton in 1798 belongs to family Anacardiacae. It has diverse common names depending upon the region, Charoli (Gujarat), Chawar, Achar, Cuddapah almond (Bengali), Piyal (Assam) Charu (Oriya), and Char (Telugu). The species is a native of the Indian sub-continent ${ }^{1}$ and is found in the tropical deciduous forests of north, western and central India. Chironji is a hardy plant and thrives well on rocky, gravelly red soils and also on saline and sodic soils but does not survive under water logged conditions. It grows in pockets of soil between crevices of barren rock and degraded rocky areas including salt-affected soils. For better growth and productivity, well-drained deep loam soil is ideal and it prefers tropical and subtropical climate and withstands drought admirably. It is found growing naturally in the forests of north, western and central
India mostly in the states of Madhya Pradesh, Bihar, Orissa, Andhra Pradesh, Chhattisgarh, Jharkhand, Gujarat, Rajasthan and Maharashtra ${ }^{2}$. The species is closely associated with Sal (Shorea robusta), Teak (Tectona grandis) and Anogeissus species.

Buchanania lanzan is a medium-size tree, and grows up to $40-50 \mathrm{ft}$. with a straight trunk. The trees are found up to an altitude of 900 meters above mean sea level. Trees have the alternate bearing nature as present in the mango which flowers from January to March and fruits ripen in the month of April-June ${ }^{3}$. The leaves are 6-10 inches long, with oblong, obtuse, flowers whitish green, sessile, fruit drupe, green when immature and dark black at the ripened stage.

How to cite this article: Prasad, S. (2020). Chironji (Buchanania lanzan): A Retreating Valuable Resource of Central India. International Journal of Bioresource Science, 7(1): 01-04.

Source of Support: None; Conflict of Interest: None (क) 9 
Fruits are juicy with moderate sweet and acidic pulp generally collected at the green stage to extract the kernels. Chironji is one of the most common dry fruits in India which contains a high calorific value and sweetish in flavor. It used frequently as snacks and as an ingredient in several traditional sweets of India. On average, $40-50 \mathrm{~kg}$ of fresh fruits are produced per tree, which remains $8-10 \mathrm{~kg}$ on drying, resulting in 1-1.5 $\mathrm{kg}$ of finished product per tree. The price of the dry seed of Chironji is about ₹ $1200-1500$ per kilogram.

\section{Use of this vegan product:}

- Food: Charoli seeds are a popular ingredient in Indian sweets (Chironji ka Barfi, Piyush, shrikhand, kheer and halwa), meaty kormas, lamb pepper with Chironji, Gajar ka Meetha, Hyderabadi Haleem, Charoli mutton, Malai kofta and as a flavoring for batters and sauces.

- Medicine: Medicine: Ayurvedic medicine uses all the parts of this tree including its bark, fruits, roots, leaves, nuts and kernels for its varied medicinal properties in treating cold, bowel disorders, premature ejaculation, fever and rheumatism. The gum extracted from the bark of this tree and powder of the roots and dried leaves mixed with buttermilk is a traditional remedy for treating diarrhea. In the folklore medicine of Andhra Pradesh, Chironji gum was mixed with cow's milk for relieving rheumatic pain and they also used the leaves as a tonic for supporting cardiac functions. The leaf powder was also used in encouraging the quick healing of wounds. The juice or the decoction of the Chironji leaves is being used in Unani medicine for purifying the blood, treating loss of libido, impotency and also as a tonic for the digestive system.

- Cosmetic: Powdered seeds blended with milk and turmeric powder is used in India since as a natural face pack for augmenting the glow, complexion and suppleness of the skin.

\section{Nutritive Value}

Buchanania lanzan is nutritional, palatable and used as a substitute for almonds in confectionery. The edible seed kernels of Chironji contain a pleasant, slightly acidic flavor, and are eaten raw or roasted.
It yields fatty oil known as Chironji oil which is the best substitute of olive and almond oils in both confectionery and indigenous medicine used for glandular swellings of the neck. Fruits are laxative and also used as an alternative medicine to relieve fever. Kernels of fruits are also used as an ointment in skin diseases ${ }^{4}$. It has great potential in employment generation, particularly for forest dwellers. An estimate tells that the total potential of Chironji in undivided Madhya Pradesh yields about 5000 tonnes per annum that can generate 8 lakh man-days of employment. (http://jhamfcofed.com/ resources/chironji.htm). Bassed on the economic potential of the species, the Planning Commission adopted the species for enterprise development for central India under $12^{\text {th }}$ five years plan. The nutritional assessment of Chironji is presented in table 1.

Table 1: Nutritional content in Chironji (per single unit of Kerenel)

\begin{tabular}{ll}
\hline Fat & $59 \mathrm{~g}$ \\
Protein & $63-72 \%$ \\
Starch & $12.1 \%$ \\
Phosphorus & $528 \mathrm{mg}$ \\
Riboflavin & $0.53 \mathrm{~g}$ \\
Niacin & $1.5 \mathrm{~g}$ \\
Vitamin C & $5.0 \mathrm{~g}$ \\
Oil & $34-47 \%$ \\
Mineral like calcium & $279 \mathrm{mg}$ \\
Vitamin like Thiamene & $0.69 \mathrm{mg}$ \\
\hline
\end{tabular}

Source: ${ }^{5}$

\section{Regeneration potential}

The species is naturally regenerated through seed but natural regeneration is limited due to the high extraction of seeds. People often cut branches to maximize extraction. Scientific studies on sustainable harvesting protocols need to be developed to enhance the regeneration of the species. Apart from this best harvesting period of Chironji fruit/seed needs to be determined. A study Sharma ${ }^{6}$ found that the best results in terms of seed size, seed weight, germination percent, oil content, etc., in the fruits harvested is obtained in the $2^{\text {nd }}$ week of May'

The major problem in the artificial regeneration of Buchanania lanzan is the low germination rate of seeds due to fungal contamination associated with 
the storage of seeds. Moreover, the fungal attack by Fusarium sp. (wilting disease) is common after sowing the seeds. The seedlings are also attacked by Fusarium monililforme var. subglutinans, F. semitectum present in soil ${ }^{7}$. Humidity and high temperature are also conducive to fungal contamination. At higher humidity and seeds exposed to sunlight for longer periods fail to germinate and lose their viability very soon. The hard seed coat is another problem that leads to low germinating capability ${ }^{8}$ but about $83 \%$ germination could be achieved by the mechanically breaking of stony endocarp before sowing in beds. Plant survival of 93-96 \% with satisfactory plant growth is obtained when one-year seedling is planted in $60 \times 60 \times 60 \mathrm{~cm}$ pit filled with red soil and $10 \mathrm{~kg}$ of well rotten FYM coupled with proper mulching around plants during winter and summer season and with or without thatching ${ }^{9}$. To avoid water logged conditions, seeds can be sown on raised beds or in polythene bags. The long gestation period of 15-20 years is another problem with Charonji plants along with large genetic variability. Therefore, to ensure future regeneration of the species, some breeding operations are required. Plant tissue culture might be one of the most useful technologies to propagate the germplasm in a mass volume.

\section{Vegetative propagation}

Vegetative propagation always considered a means of large scale production of germplasm under various forestry operations. The following methods of vegetative propagation could be viable for the regeneration of Chironji.

Soft wood grafting-method is useful for establishing in situ Chironji orchard in gravelly soils and drier tracts where mortality of nursery raised grafts is very high. Freshly extracted seeds are sown in polythene bags for germination. After attaining a height of $5-10 \mathrm{~cm}$, it can be directly planted in the field at the desired distance. These vigorous seedlings, attaining pencil thickness after one year are soft wood grafted with scion sticks of suitable genotype. The main advantages of this method are better plant growth and minimum mortality.

Chip budding: It is reported as one of the successful methods of vegetative propagation ${ }^{10}$ of Chironji. In this method of budding, a healthy bud is selected in the axil of 2 months old leaf emerging on a new flush. The leaf-blade is removed with the help of a sharp blade leaving petiole intact. Upper cut is given about $2 \mathrm{~cm}$ above bud which goes downwards, taking wood portion with simultaneously, up to 1.0$1.5 \mathrm{~cm}$ below the bud, then the lower cut is given about $1.0 \mathrm{~cm}$ below bud to take out bud with wood. Some rectangle cut is made on root stock and the bud is placed at the juncture. Bud is pressed by hand to remove open space if any and tied tightly with a white polythene strip. After union, top of seedlings is cut a little above bud union and polythene strip are carefully removed. If the selection of scion and root stock is proper, appreciable success may be obtained during July -August.

Root cutting-ensured varying degree of success as poor viability of seeds and slow growth of seedlings, Buchanania specie has not so far been raised in plantation despite the high price of kernels in the market. Rooting in root cuttings is difficult however, with the use of some growth hormones like auxins, appreciable success is obtained. Two year old root cuttings having a thickness of 3.6-5.5 $\mathrm{cm}$, treated with IAA (1600ppm) recorded $67.66 \%$ rooting ${ }^{11}$. Root cuttings are successful, but the method has limited use as it results in serious injury to the plant when a large amount of root cuttings are taken. Moreover, tap root is also absent which affects longevity. Under this method, one should always follow the protocol to remove few roots on opposite sides.

Root-stock- controls vigor and equilibrium between yield and quality therefore considered as a good means of vegetative propagation of Charonji.

\section{Conservation}

B. lanzan is included in the Red Data Book published by the International Union for Conservation of Nature and Natural Resources (IUCN) as it is a vulnerable medicinal plant. The species is facing severe genetic erosion as a result of activities related to afforestation in tribal inhabited areas ${ }^{12}$. In most of the central Indian states, it declares a non-nationalized NTFP and it is free for harvesting. Local inhabitants take advantage of and diminish the trees. Things went worst as collectors are not bothering about the cultivation.

Many workers reported that indiscriminate harvesting; cutting branches to the rampant 
collection of seeds and lopped trees attract the infestation of insect pests which adversely affect the growth and productivity. Moreover, trees have suffered due to mortality caused by some biotic factors i.e. grazing, repeated fire, indiscriminate harvesting (lopping and cutting), disease and insect pests $^{13,14,15}$. No organized cultivation of Chironji is practiced and fruits are directly collected from the wild trees occurring in the forest and marginal lands by un-scientific manner, therefore, the species is facing a great threat. Occasionally the trees are cut partly or completely by the tribals to collect the fruits. Trees have been completely wiped off in the recent past due to developmental activities and the expansion of agricultural land. Such condition has led to the demolition of natural patches of the species. There are no standard cultivars available in Chironji since little work has been done to exploit genetic resources.

At present processing of Chironji nut is done manually and some time by locally made machine. This traditional process involves soaking in the water for $24 \mathrm{hrs}$, skin removal by hand rubbing followed by drying. Dried nut is broken by rubbing between a pair of stone-slab or hammer followed by separation of the kernel from the hull. In some areas local artesian developed motorized machines for breaking and separating, but the machines were not specifically designed. So, they are again manually separating. Therefore, there is a need for developing the machinery for Chironji decorticating ${ }^{16}$.

\section{CONCLUSION}

The above mentioned facts reveal that the species have a good nutritive value and economic potential. Although, regeneration is poor due to unscientific exploitation of seeds but vegetative propagation could be a viable means of reproduction. Several seedling strains with a lot of variation provide scope for selection of better varieties ${ }^{12}$ and when propagated by seed for root stock preparation, $80-85 \%$ germination is achieved. Conservation of Chironji has emerged as a big issue amongst conversationalists and environmentalists in India. The species listed in the vulnerable group of the Red data book of IUCN. As Chironji is a highly nutritious seed having potential industrial and domestic uses therefore, conservation approaches for this valuable species should be cultivationoriented.

\section{REFERENCES}

1. Zeven, A.C. and JMJ De Wet, 1982. Dictionary of Cultivated Plants and Their Regions of Diversity: Excluding Most Ornamentals, Forest Trees and Lower Plants. Wageningen: CAPD.

2. Hemavathy, J. and Prabhankar, J.V. 1988. Lipid com position of Chironjee kernel. J. Food Com pos. and Anal., 1: 366-370.

3. Troup, R.S. 1986. The Silviculture of Indian Trees. International Book Distributors, Dehradun, India.

4. Das, D. and Agrawal, V.S. 1991. "Fruits drug plants of India", Kalyani Publishers, New Delhi, pp. 250.

5. Gopalan, C., Ramashastri, B.V. and Balasubramaniam, S.C. 1982. Report, National Institute of Nutrition, Hyderabad, A.P. (INDIA).

6. Sharma, A. 2012. Scientific Harvesting for Quality Seed Collection of Buchanania lanzan Spreng for its Conservation and Sustainable Management-Case Study of Chhindwara, Madhya Pradesh, India. International Journal of Bio-Science and Bio-Technology, 4(1).

7. Sharma, N., Ghosh, R. and Nigam, M. 1998. Toxigenic fungi associated with stored fruits of chironji. Indian Phytopathol., 51: 284-286.

8. Shende, S. and Rai, M. 2005. Multiple shoot formation and plant regeneration of a commercially-useful tropical plant, Buchanania lanzan (Spreng). Plant Biotechnology, 22(1): 59-61.

9. Shukla, S.K. and Solanki, K.R. 2000. Studies on seed germination, plant survival and growth of chironji (Buchanania lanzan Spreng.). J. Tropical Forest, 16(1): 44-49.

10. Tewari, R.K. and Bajpai, C.K. 2001. Propagation of Chironjee (Buchanania lanzan Spreng.) by chip budding. Agro. for. Newsletter, 13(1\&2): 1-2.

11. Singh, J., Banarjee, S.K. and Francis, A. 2002. Vegetative propagation of Buchanania lanzan Spreng root cuttings, Indian Forester, 128: 700-704.

12. Singh, S. 2007. Chironji In: Peter KV (ed) Underutilized and underexploited Crops, vol 2. New India Publishing Agency, New Delhi, pp. 295-309.

13. Beeson, C.F.C. 1941. The ecology and control of forest insect of India and neighboring countries. Vasant Press, Dehradun, pp. 767.

14. Bhasin, G.D., Roonwal, M.L. and Singh, B. 1958. A list of insect pests of forest plants in India and the adjacent countries. Pat 3. Indian Forest Bulletin (NS). Manager of Publication, Govt. of India, New Delhi, 17: 1-11.

15. Browne, F.G. 1968. Pests and diseases of forest plantation trees. Clarendon Press, Oxford, pp. 1330.

16. Kumar, J., Vengaiah, P.C., Srivastav, P.P. and Bhowmick, P.K. 2012. Charonjii Nut (Buchanania lanzan) processing, present practice and scope. Indian Journal of Tropical Knowledge, 11(1): 202-204. 